\title{
Osmanlı Devleti’nde Yurtdışı Eğitimin Öncüleri (1830-1839) ${ }^{1}$
}

\author{
Mustafa GENÇOĞLU \\ Doç.Dr. Uşak Üniversitesi, Fen-Edebiyat Fakültesi, Tarih Bölümü, Uşak, Türkiye \\ mustafa.gencoglu@usak.edu.tr \\ ORCID: 0000-0002-5276-7241
}

\section{$\ddot{\mathbf{O z}}$}

Sultan II. Mahmud, gruplar halinde Avrupa'ya öğrenci göndermek suretiyle Osmanlı Devleti'nde yurtdışı eğitimi başlatan ilk Osmanlı padişahıdır. İlk olarak Serasker Hüsrev Paşa'nın evlatlıkları Fransa'ya tahsile gönderilmiştir. Bunların tahsildeki başarılı performansları daha sonraki öğrenciler için yurtdışı eğitimin kapısını ardına kadar açtı. Bu süreçte Avusturya, İngiltere, Fransa ve Prusya'ya çeşitli eğitim alanlarında ve muhtelif sayılarda öğrenciler gönderildi. Öğrencilerin hemen hemen hepsi askeri menşeliydi. Onlar yeni ordunun (Asâkir-i Mansûre-i Muhammediye) askerleri, Mekteb-i Harbiye ve diğer modern askeri teknik okulların (Mühendishane-i Berri-i Hümayun ve Mühendishane-i Bahr-i Hümayun) talebeleri ile Tophane, Fişenkhane, Tersane, Baruthane gibi askeri müesseselerin mühendis ve teknisyenleriydi. Yurda döndüklerinde onlardan Batıdan elde ettikleri bilgi ve beceriyi ülkeye taşımaları bekleniyordu.

Bu çalışmada Sultan II. Mahmud'la 1830'da başlayan yurtdışı eğitimin Tanzimat'a kadar nicelik ve nitelik olarak değerlendirilmesi amaçlanmaktadır. Dolayısıyla yurtdışı eğitimin amac1, öğrenci sayısı, eğitim alanları, tercih edilen ülkeler gibi konular tartış1lacaktır. Böylece Osmanlı devletinde yurtdışı eğitimin ilk safhasının genel karakteristiği belirlenmeye çalışılacaktır.

Anahtar Kelimeler: Yurtdışı eğitim, II. Mahmud, Osmanlı öğrencileri, Eğitim, Modernleşme, Avrupa

\section{Pioneers of the Study Abroad in the Ottoman State (1830-1839)}

\section{Abstract}

II. Mahmud is the first Ottoman sultan who started the study abroad in the Ottoman State by sending students to Europe in groups. First of all, Serasker Hüsrev Pasha's adopted children were sent to France for education. Their successful performance in education has opened the door wide to the study abroad for the future students. During this period, students

\footnotetext{
${ }^{1}$ Bu çalışma, YÖK Yüksek Öğretim Dergisi’nin 18. sayısında (s. 21-26) yayınlanmış olan “Osmanlı'da Yurtdışı Eğitimin Başlangıcı (1830-1839)" başlıklı makalenin akademik üslupla yeniden ele alınıp genişletilmiş halidir.
} 
in various fields of education and in various numbers were sent to Austria, England, France and Prussia. Almost all of the students were of military origin. They were the soldiers of the new army (Asâkir-i Mansûre-i Muhammediye), officiers and students of Mekteb-i Harbiye and other modern military technical schools (Mühendishane-i Berri-i Hümayun and Mühendishane-i Bahr-i Hümayun) and engineers and technicians of military establishments such as Tophane, Fişenkhane, Tersane. On their return to home, they were expected to bring the knowledge and skills they gained from the West to the country.

In this study, it is aimed to evaluate the study abroad, which started with Sultan Mahmud II in 1830, in terms of quantity and quality until Tanzimat. Therefore, subjects such as the purpose of study abroad, number of students, fields of education, preferred countries will be discussed. Thus, the general characteristics of the first phase of study abroad in the Ottoman state will be tried to determine.

Keywords: Study abroad, Mahmud II, Ottoman students, Education, Modernization, Europe

\section{Giriş}

Sultan II. Mahmud, gruplar halinde Avrupa'ya öğrenci göndermek suretiyle Osmanlı'da yurtdışı eğitimi başlatan ilk Osmanlı padişahıdır. Aslında bu husus ilk olarak I. Abdülhamid zamanında gündeme gelmiştir. Dönemin sadrazamı Halil Hamit Paşa, 1784'te, İstanbul'da bulunan Fransız Büyükelçisi Choiseul - Gouffier ile Fransa'ya 30 öğrenci yollanması hakkında anlaşmaya varmıştır (Unat, 1964: 129; Akınc1, 1973: 30). Gerçekleşmeyen bu girişimin akabinde ikinci adım, III. Selim'in saltanatında Ebubekir Râtib Efendi'nin, reisülküttap iken Fransa'nın Fevkalade Orta Elçisi Raimond Verninac (1762-1882) ${ }^{2}$ ile yaptığı resmi görüşmede atılmıştır. Râtib Efendi, Paris'te Osmanlı tebaasından 9-10 yaşlarındaki çocukların devam edeceği bir okul kurmayı hedeflemekteydi. Bu okula gidecek öğrenciler, Fransızca öğretildikten sonra Osmanlı Devleti'nin ihtiyaç duyduğu alanlarda yetiştirileceklerdi. 10 yıllık eğitim programını tamamlayan öğrenciler, yurda döndüklerinde bir taraftan Osmanlı Devleti'nin yabancılara olan ihtiyacını azaltacak diğer taraftan da reformlar için gerekli bilgiyi üreteceklerdi (Yeşil, 2010: 420-421). Dolayısıyla yurtdışına öğrenci gönderme girişimleri, 1830'a kadar kuvveden fiile geçmemekle birlikte 1856'da

2 1795'de İstanbul'a Fevkalade Orta Elçi olarak gönderilmiş, ertesi sene geri çağrılmıştır. (Soysal, 1987: $355)$. 
Paris'te kurulmuş olan Mekteb-i Osmani'nin çok önceden tasarlandığını ortaya koyması bakımından önemlidir.

Bu çalışmada 1830'da II. Mahmud'la başlayan yurtdışı eğitimin Tanzimat'a kadar nicelik ve nitelik olarak değerlendirilmesi amaçlanmaktadır. Bu minvalde yurtdışı eğitimin amacı, gönderilenlerin sayısı ve eğitim alanları, tahsil görülen ülkeler gibi konulara değinilerek Osmanlı'da yurtdışı eğitimin ilk safhasının genel karakteristiği belirlenmeye çalışılacaktır.

\section{Amaç ve İlk Deneyim}

II. Mahmud (1808-1839) oldukça geniş ve kapsamlı bir yenileşme hareketine girişmiş ve bu minvalde Batılı tarzda birçok modern müessesenin kurulmasına öncülük etmiştir. Onun zamanında ilk defa modern nüfus sayımı ve mülk yazılımı yapılmış, modern posta sisteminin kurulması, pasaport ve karantina usullerinin kabulü gibi yeniliklere gidilmiştir (Karal, 1988: 155, 156; Karpat, 2006: 524). Türk basınının öncüsü konumundaki ilk resmi gazete, Takvim-i Vekâyi de bu dönemin ürünüdür (Yazıc1, 2010: 490-492). II. Mahmud kendinden öncekilerden farklı olarak sosyal ve kültürel alanlarda da reformlara girişmiştir. Kıyafet reformu uygulamaya sokulduğu gibi, Batı kültürünün unsurları olan sandalye ve masalar gözükmeye ve bazı Avrupalı sosyal adetler benimsenmeye başlandı. Perşembe günü Fransa' daki gibi resmi tatil ilan edildi. Tasvir-i Hümayun denilen sultanın resimleri devlet dairelerinin duvarlarına astırıldı (Lewis, 2000: 102, 103). İlkokulu zorunlu hale getirme çabaları da ilk kez onun zamanında görülür (Akyüz, 2013: 151-152). Bu dönemde Müslüman unsurun dil ve diplomasi eğitimi için Tercüme Odası kurulurken (1821) (Akyıldız, 2012: 52) nezaretler ve meclislerle modern bürokrasinin temelleri atılmıştır (Findley, 2014: 155, 163-171; Seyitdanlığlu: 1999).

Sultanın ülke yönetiminde ve reformlarında takip etmiş olduğu siyasetin en belirgin özelliği, Avrupa'daki çağdaşları gibi modern merkeziyetçi devlet anlayışını benimsemiş olmasıdır (Mardin, 1994: 12). Rusya ile yaptığı savaştan sonra (1812) ilk olarak, merkezden bağımsız hareket eden eyaletlerdeki ayanları bastırdı. Ardından da, reformları içerisinde öncelik taşıyan modern bir ordu teşkiline girişti. Henüz kuruluş aşamasında, bu girişime karşı ayaklanan Yeniçeriler, kanlı bir şekilde bastırılarak tarih sahnesinden silindiler (16 Haziran 1826). Merkezi idarenin kuvvetlenmesi ve özellikle Yeniçeriliğin lağvıyla yeniliklere direnen en ciddi örgütlü muhalefetin ortadan 
kaldırılması, II. Mahmud'a büyük bir reform programını devreye sokması için iyi bir zemin sağladı (Davison, 1997: 37). İlk olarak kaldırılan Yeniçerilerin yerini Asâkir-i Mansure-i Muhammediye isimli yeni ve modern bir ordu aldı (Karal, 1988: 150-151). Fakat teknik donanımlarından giyimlerine kadar yenilenen Osmanlı askerlerine Batılı tarzda eğitim verecek yeterli subay yoktu. Bir an önce bu eksikliğin giderilmesi için düşünülen ilk çare, Mısır Valisi Mehmed Ali Paşa'ya başvurmak oldu. Mehmed Ali, uzun süre önce ordusunun modernleştirilmesi yönünde ciddi adımlar atmış ve Fransız subaylarından aldığı destekle bu konuda büyük bir yol kat etmişti. Fakat Mısır'dan istenilen on iki subay, çeşitli bahaneler öne sürülerek gönderilmeyince (Ahmed Lütfi Efendi, 1999: 143) Tıpkı seleflerinin önceden başvurdukları gibi Avrupa ülkelerine yönelmek zorunda kalındı. Ancak yeni ordunun eğitimini tümüyle yabancı subaylara emanet etmek uzun vadede rasyonel değildi. Modern kara ordusunu sevk ve idare edebilecek subayların yetişmesi için askeri bir okul şarttı. Talimhâne ve Sıbyan Bölükleri gibi tecrübelerin ardından asıl büyük adım ilk modern kara harp okulu olan Mekteb-i Ulûm-ı Harbiye (1834) ile atıldı (Mehmed Esad, 1310: 9, 10, 12, 17; Ergin, 1939: 302-303, 306-310). Bu okulla birlikte modern ordunun bando ihtiyacın1 karşılamak için Muzika-i Humâyûn Mektebi açıldı (Ergin, 1939: 311-315). Bunlardan daha önce 1827 'de faaliyete sokulan modern Tibbiye'nin amac1 da yeni ordunun ihtiyaçlarını karşılamaya yönelikti. Tıphâne-i Âmire adıyla açılan bu okul 1831'de kurulmuş olan Cerrahhâne'yle birleştirilerek 1838'de, Mekteb-i Tibbiye-i Adliye-i Şâhâne adını almıştır (Rıza Tahsin, 1328: 3, 7, 9). Bunların yanında daha önce açılmış modern denizcilik (Mühendishane-i Bahr-i Hümayun, 1773) ile kara topçu (Mühendishane-i Berri-i Hümayun, 1795) okulları da ihmal edilmemiş, çeşitli yeniliklerle desteklenmiştir (Shaw, 2010: 78-79).

Yeni ordunun askeri eğitiminde batılı uzman kadrolara başvurma mecburiyeti, söz konusu modern askeri okulların öğretim kadroları için de geçerliydi. Mekteb-i Harbiye olmak üzere askeri okullar için çağdaş bilgilerle donanmış askeri hocalar ile yetenekli subaylara ihtiyaç vardı. Ayrıca, Tophâne, Baruthâne, Fişenkhâne, Dökümhâne, Tersane gibi askeri müesseselerde çalışacak ehliyete sahip mühendis subay ve teknik eleman açığının da kapatılması elzemdi (Mehmed Esad 1312: 65). Özellikle Navarin'de yakılan donanmanın yeni teknolojik gelişmelere uygun şekilde tekrar ihya edilmesi, bu hususta bilgi sahibi teknik elemanlara bağlıydı. Yabancı 
hocaların ve uzmanların maliyetleri yüksek olduğu kadar verimli oldukları da şüpheliydi. Hiç aşina olmadıkları bir kültür ve bilmedikleri bir dille kısa bir sürede faydalı olabileceklerini düşünmek yanlıştı. Onun için bu topraklarda yetişmiş, üstüne Batı dilini ve bilimini membaından öğrenmiş, idealist kadroların bir an önce yabancıların yerini alması gerekiyordu (Uluçay 1958: 95-96). Bu amaç ve beklentiler, Avrupa'ya öğrenci gönderme projesini gündeme getirmiştir. Nitekim Batılı usulde kurulan müesseselerin başarısı ve gerçekleştirilen köklü reformların sürdürülebilirliği Batıdan bilgi ve teknoloji transferine bağlıydı. Bunun da direkt ve en kestirme yolu yurtdış1 eğitimden geçmekteydi. Bu konuda imparatorlukta merkezi idareden önce harekete geçen Mısır Eyaleti, 1815'te ilk öğrencisini İtalya'ya göndermişti. Mısır'ı adeta bağımsız bir sultan gibi yöneten Mehmed Ali, Mısır'ın modernleşmesi için başta askeri olmak üzere birçok alanda ciddi bir reform programını devreye sokmuştu. $\mathrm{Bu}$ bağlamda Batıdan uzman ve teknisyenler getirttiği gibi Avrupa'ya öğrenci göndermeye başlamıştı. Mısır için modernleşmede temel model olan Fransa yurtdışı eğitim için de başlıca adres olmuş; Paris’te, 1826-1833 arası faaliyet gösteren Ecole Egyptienne'de birçok Misırlı öğrenci okutulmuştur (Şişman 2004: 3, 4). Aslında devasa boyuttaki iç ve dış sorunlarla boğuşmak zorunda olan Osmanlı Sultanı, şüphesiz Batı ile olan gelişmişlik farkını ortadan kaldırmada valisinden çok daha istekliydi.

Mahmud Cevad (2001: 6), II. Mahmud'un, 1246'da (1830) Avrupa'ya 150 talebe gönderilmesini emrettiğini ve bunların da Enderun ve Tıbbiye öğrencilerinden seçilmesine karar verildiğini belirtmektedir. Aynı yazar, halk arasındaki söylentilerden çekinildiği için yollanacak öğrencilerin seçiminde karar değişikliğine gidilerek, Harbiye Mektebi ve Hendesehâne-i Âmire öğrencilerinden 150'sinin gönderildiğini ifade etmektedir. Yaptığımız araştırmalar neticesinde Avrupa'ya bir anda 150 kişi birden gönderildiğine dair arşivde bir belgeye rastlamadık. Ekonomik külfet ve öğrencilerin denetimi meselesi düşünülürse bunun pek mümkün olmadığı da anlaşılır. Eğer yukarıdaki sayıyı, II. Mahmud dönemi sonuna kadarki süreç için kabul edersek, incelemelerimiz sonucunda, bu süreçte gönderilenlerin sayısı toplam 89 olup, bunların içerisinde tespit edebildiğimiz Mekteb-i Harbiye ve Mühendishâne-i Berriye ve Mekteb-i Bahriye mezunlarının toplam sayısı 30'dur (Gençoğlu, 2008a: 21). 
İkinci mesele, belirtilen tarihte yani 1830 'da, ilk defa yurtdış1 eğitimi için Avrupa'ya gönderilen Osmanlı öğrencileri, yukarıda belirtildiği gibi Mekteb-i Harbiye ve Mühendishane mezunlarından değil, Serasker Hüsrev Paşa'nın himayesinde olup sarayda "Daire-i Seniye'de" tahsil görmüş Hüseyin, Abdüllatif, Ahmed ve Edhem efendilerdir. $\mathrm{Bu}$ dört öğrenci, 1830'un son günlerinde, dönemin ünlü oryantalistlerinden Amédée Jaubert (1779-1847)'in refakatinde bir yelkenliyle İstanbul'dan yola çıkmışlar ve Şubat başında Marsilya'ya, Mart ayında ise Paris'e ulaşmışlardır. Burada, yatılı bir okul olan Institution Barbet'te dil öğrenmişlerdir (Eldem, 2006: 51, 52; Şişman 2004: 5). Daha sonra Abdüllatif Efendi 'askeri fünun', Hüseyin Efendi ise hendese ve topçuluk üzerine öğrenim görmüşlerdir (BOA, HAT, 33726-A; Şişman, 2004: 5-6). Bu iki askeri öğrenci, Mayıs 1838'de İstanbul'a dönmüşlerdir (BOA, HAT, 33474). Hüseyin Efendi, Mekteb-i Tibbiye'deki memuriyetinden sonra yurtdışındaki ihtisasına uygun olarak 1840 'da Tophane-i Âmire'ye atanmış ve rütbesi Binbaşllığa terfii ettirilmiştir (BOA, C.AS, 32428). Aynı y1, Abdüllatif ve Fransa'da öğrenim görmüş olan diğer subaylarla birlikte görevli olarak Paris'e gitmiştir (BOA, HAT, 58137; BOA, İ.HR, 149; BOA, C.MF, 2521). Kaynaklardan Hüseyin'in Ferikliğe kadar yükseldiği, Abdüllatif' in ise Erkân-1 Harbiye Miralaylığındayken 1914'ten önce vefat ettiği bilinmektedir (İkdam, 14 C evvel 1332 (10 Nisan 1914); İnal, 1940: 601).

Diğer iki kişiden Ahmed Efendi, Brest Bahriye Okulu'nu bitirdikten sonra, Fransız Donanmasına ait bir gemide, iki yıl da staj yapmıştır. Nihayet Haziran 1839'da, bir Fransız Generali tarafindan yapılan haritayı ulaştırmak göreviyle ve Tersâne-i Âmire'de istihdam olunmak üzere Paris'ten İstanbul'a yollanmıştır (BOA, HAT, 48162-Z/2). Osmanlı Bahriyesinde Firkateyn Süvarisi olmuş (İnal 1940: 601), 1840 'da, diğer arkadaşlarıyla birlikte inceleme gezisi için tekrar Paris'e gönderilmiştir.

$\mathrm{Bu}$ dört kişi içerisinde hakkında en fazla bilgiye sahip olduğumuz kişi, sadrazamlı̆ga kadar yükselmiş olan Edhem Efendi, tam adıyla İbrahim Edhem Paşa'dır (1818-1893) (İnal, 1940: 600-635; Uzunçarş11, 1948: 67-70; Eldem, 2006: 50-53). Paşa, aslen Sakızlı bir Rum olup, Hüsrev Paşa'nın evlatlıklarındandır. Institution Barbet'den sonra 1835 'te girdiği Madencilik Okulu'ndan (Ecole des Mines) 1838 'de mezun olmuştur. Bir müddet Avrupa'daki madenleri inceledikten sonra 1839'un son çeyreğinde İstanbul'a döndü (Gençoğlu, 2008a: 23). Miralaylık rütbesiyle Dâr-l Şûrâ- 
yı Askeriye'ye atanmasını (BOA, C.AS, 29175) müteakip kendisi gibi Fransa'da öğrenim görmüş diğer arkadaşlarıyla birlikte tekrar Paris'e gönderilmiştir (1840) (BOA, İ.HR, 149). Sarıyer bakır madeni ve Gümüşhacıköy Madeni müdürlüklerinden sonra Keban ve Ergani madenleri başmühendisi oldu (1845). 1851'de Mabeyn-i Hümayûn Ferikliği'ne yükselen Paşa, bu esnada Sultan Abdülmecid'e Fransızca dersler vermiştir. Edhem Paşa, Meclis-i Âli-i Tanzimat, Meclis-i Vâlâ, Encümen-i Dâniş üyeliklerinde bulunduktan sonra muhtelif nazırlık ve elçilik görevlerinde bulunmuştur. $1877^{\prime}$ de getirildiği sadaret makamından bir yıl sonra alınmıştır. Viyana Sefirliği'nden sonra Dahiliye Nazırı olarak görev yaptığı Kabinenin düşmesiyle, $1885^{\prime}$ te emekliye ayrılmıştır. Paşa, maden mühendisliğinde olduğu gibi tabii ilimlerde de derin bilgi sahibiydi. Местиа-i Fünûn'da tabii ilimlere dair makaleler yazmıştır. Rasathâne ve Matbaa-i Âmire'nin 1slahında, Dârüşşafaka'nın kurulmasında büyük bir emeği vardır. Oğullarından Osman Hamdi ve Halil Edhem (Eldem) de kendisi gibi yurtdışı tahsil görenlerdendir.

Bu dört öğrenciye, Ocak 1832'de, yine Hüsrev Paşa'nın evlatlıklarından olan Mehmed Reşid Bey de katılmıştır (BOA, C.HR, 6708). Asâkir-i Mensure subaylarından Mehmed Reşid, Paris'te, askeri alanda ve özellikle topçuluk üzerinde tahsil görmüştür (BOA, HAT 59189). Eğitimi devam ederken, 1836'da rütbesi Kaymakamlığa terfii ettirilmiştir ( BOA, C.AS, 54029). 1838' in sonlarında öğrenimini tamamlamış ( BOA, HAT, 26117-B ) ve 1839'da İstanbul'a dönmüştür (BOA, HAT, 26117). Çok hızlı bir ilerlemeyle döner dönmez ilk önce rütbesi Miralaylığa yükseltilmiş, (BOA, HAT, 33714-F, 18615-D) çok kısa bir süre içerisinde de Mirlivalıkla atandığı Tophane'de Ferikliğe terfi ettirilmiştir (1840) (BOA, HAT, 59189, 58137; BOA, İ.HR, 149). Aynı yıl Mehmed Reşid Paşa Dâr-ı Şura-yı Askerî üyesi olmuştur. Aralık 1847 'de vezirlik rütbesiyle Anadolu Müşirliğine getirilmiştir. Ağustos 1851 'de Tophâne-i Âmire Müşirliğine tayin olmuş, fakat aynı yılın Eylül ayında vefat etmiştir (Mehmed Süreyya, II, 1311: 393).

İlk etapta Hüsrev Paşa'nın evlatlıkları olan bu çocukların gönderilmesi, yurtdışı eğitim için bir prova niteliği taşımaktaydı. Her ne kadar Hüsrev Paşa, evlatlıklarını kendi bütçesiyle Paris'e göndermişse de, padişahın bilgisi dışında böyle bir teşebbüse girişilemeyeceği gibi bu çocukların döndükleri zaman yine devlet hizmetinde kullanılacak olmaları bunun önceden kararlaştırılmış bir proje olduğuna 
işaret etmektedir. Nitekim 28 Safer 1254 / 23 Ağustos 1838 tarihli (BOA, HAT, 33474) belgede o esnada Meclis-i Ahkâm-1 Adliye Reisi olan Hüsrev Paşa'nın, tahsil masraflarını üstlendiği 5 talebeden ikisinin Paris’ten döndüğü, kalan üçünün ise tahsillerini tamamlayabilmeleri için bir müddet daha kalmaları gerektiği bildirilmektedir. Hüsrev Paşa'nın bu çocukları okutmasındaki amacının, onların devlet hizmetinde istihdamları olduğu belirtildikten sonra, tahsilleri devam eden 3 kişinin masraflarının devlet tarafından karşılanması talebi kabul edilmiştir. Hüsrev Paşa'nın Paris’te tahsilde olan evlatlıklarına gönderdiği mektuplarında da, devletin Avrupa'ya öğrenci gönderme kararında onların gösterecekleri başarının etkili olacağ vurgulanmaktaydı. Paşa 4 Şubat 1831'deki mektubunda, “çok çalışmaları gerektiğini ve hiçbir şey öğrenmeden döndükleri takdirde bunun ne kadar utanç verici olacağını" yazıyordu. 15 Haziran 1832 tarihli ikinci mektubunda ise, Fransa'da eğitim görmeleri için yetiştirdikleri arasından onları seçerken, Müslüman gençliğin eğitimi için bütün umutlarını onlara bağlamış olduğunu belirtiyordu. Devamında, "devlet büyüklerimiz size bakarak benim örneğimi takip edip etmeyeceklerine ve çocuklarının geleceğini Avrupa'nın ilmine emanet edip etmeyeceklerine karar vereceklerdir" diyordu (Eldem 2006: 51-52). Hüsrev Paşa'nın ifade ettiği gibi evlatlıklarının başarısı, Batıya sistemli bir şekilde öğrenci gönderilmesine ve bu suretle Osmanlının yurtdışı eğitim yolunun açılmasına vesile olmuştur.

\section{Gönderilen Ülkeler ve Öğrenim Alanları}

Araştırmamız neticesinde yurtdışı eğitimin başlangıcından itibaren II. Mahmud döneminde Batıya gönderilen 89 öğrenci tespit edilmiştir. Bunlardan 30’u Avusturya'da, 27'si İngiltere'de, 24'ü Fransa'da, 3'ü Prusya'da tahsil görmüş olup kayıtlarda 5 kişinin hangi ülkeye gittiği belirlenememiştir.

Bu süreçte en çok rağbet gören ülke konumundaki Avusturya'da tahsil görecek ilk öğrenciler, hicrî 1251'de (1835-1836) topçu subaylarından Hauslab'a emanet edilmişlerdi. İleride mareşallik rütbesine kadar yükselerek Avusturya Devleti Tophane Nazırı olacak bu topçu subayı, Sultan II. Mahmud'un Avusturya İmparatoru ile yazışması neticesinde İstanbul'a gelmiştir. Padişahla bizzat görüştükten sonra kendisine emanet edilen talebeleri Viyana'ya götürmüş ve uzun bir süre Osmanlı askerî öğrencilerinin nezaretini üstlenmiştir (Mehmed Esad, 1310: 20). O'nun da katkılarıyla Osmanlı askerî talebelerinin eğitimine yönelik, Viyana'da bir okul 
açılmıştır (BOA, HAT, 33733-F). Bu esnada kendisinden öğrencilerin tahsillerine gereken özeni göstereceğine dair bir taahhütnamenin de alındığı görülmektedir (BOA, HAT, 32281-E). Avusturyalı nazıra, denetim hususunda yardımc1 olacağ düşüncesiyle askerî öğrencilerin başına, yine onların arasından rütbe ve tecrübe olarak daha kıdemli birisi getirilmiştir (BOA, HAT, 40833-B; 46746-B).

Hauslab, öğrencilerin eğitim durumlarını takip ettiği gibi onların her türlü ihtiyaç ve giderlerinden de sorumluydu. Öğrencilerin rütbelerinin yükseltilmesi, hocalarının ödüllendirilmesi gibi konularda önerilerde bulunuyor, yapılan masrafların dökümünü, poliçeleriyle birlikte her ay Viyana'daki Osmanlı Sefareti'ne bildiriyordu. Bu usul, Hauslab'dan sonra atanan nazırlar tarafindan da sürdürülmüştür (Gençoğlu, 2008a: 79-80).

Bu ülkeye 1835 'te ilk gidenler arasında Seraskerliğe kadar yükselmiş Çırpanlı Abdülkerim Nadir Paşa (1807- 1883) (Özcan, 1988: 253-254), Firari Ahmed Fevzi Paşa'nın kölelerinden olan İstihkâm Feriki Rüstem Paşa, Şam valiliği esnasında vefat eden Ahmed Paşa gibi önemli askeri ve idari görevler üstlenmiş subaylar vardı. Mirliva Abdi Paşa, Ahmed Mazhar Paşa, Ömer Fevzi Paşa, Ahmed Faik Paşa da Viyana'da askeri tahsil görenlerdendir (Mehmed Esad, 1310: 19, 20, 24).

Bunların dişında, Viyana’ya, terzilik öğrenmeleri için 7 hassa askeri gönderilmiştir. Bunlar iki yıl terzilik sanatını tahsil ettikten sonra Dikimhâne-i Âmire'de istihdam edilmişlerdir (BOA, C.AS, 37932). Nitekim yeni kurulan ordudaki askerlerin, batılı tarzdaki yeni üniformalarının kalıplarının çıkarılarak, dikiminin öğrenilmesi gerekiyordu. Çok geçmeden sivil elbiselerin dikimi hususunda da ihtiyaç ortaya çıkmıştır. $\mathrm{Bu}$ iş için 1838 'de Viyana'ya askerî elbise dikmeyi öğrenmeye gidenlerden bir kişinin ayrılması ve sefarethane terzisinin yanına verilmesi gündeme gelmiştir (BOA, HAT, 46752-D).

İngiltere, bu dönemde Avusturya'nın ardından tercih edilen ikinci ülkeydi. İlk öğrenciler, Mühendishane-i Berri-i Hümayun'dan, kendileri de öğrenim görmekle yükümlü İstihkâm Kaymakamı Bekir (Ferik Bekir Paşa) ve İstihkâm Alayı Emini Emin (Müşir Emin Paşa) beylerin refakatinde h. 1250-1251'de (1834-1835) gönderilen 11 kişilik bir kafileden oluşmaktaydı. Bunlar, İbrahim Efendi (Ferik Ressam İbrahim Paşa), Derviş Efendi (Kimyager Derviş Paşa), Enis Efendi (Miralay iken Kozan'da vefat etti.), Yusuf Efendi (Erkân-1 Harbiye Binbaşısı iken emekli oldu), 
Süleyman Efendi, Mahmud Efendi, Ahmed Efendi, Arif Efendi (Londra'da tahsili sırasında vefat etti.), Tahir Efendi (Mirliva Küçük Tahir Paşa), Eyüp Efendi (Ferik Eyüp Halid Paşa) ve Halil Efendi'dir (Tophane-i Amire Müşiri Halil Paşa) (Mehmed Esad, 1312: 64, 65).

Bunlardan Kimyager Derviş Paşa (1817-1878), birkaç sene Londra'da kaldıktan sonra Paris'e geçti (1838). Burada üç sene maden fakültesine (Ecole des Mines) devam etti. Tahsilini tamamladıktan sonra İtalya, Almanya ve Rumeli'deki bazı madenlerde incelemelerde bulundu ve parası devletçe karşılanan çeşitli kitap ve aletlerle birlikte İstanbul'a döndü (BOA, İ. HR, 453). Mekteb-i Harbiye Nazırlığı da yapmış olan Kimyager Derviş Paşa Türkiye'de fizik ve kimya sahalarında bilim literatürünün oluşmasında öncülük yapmıştır. Özellikle Usûl-i Kimya adlı eseri Türkçe olarak tek başına basılan ilk kimya kitabıdır. Uzun yıllar bütün okullarda temel ders kitabı olarak okutulmuştur. Eserin önsözünde Türkçenin bilim ve eğitim dili olması gerektiği hususuna değinir. Bir diğer eseri, fizik eğitimi hakkındaki Usûl-i Hikmet-i Tabiiyye'dir (Aydüz, 2008: 375-376).

Bu grupta yer alan Küçük Tahir Paşa, Londra Darülfünunu'nda matematik tahsil görmüştür (BOA. C.MF 3830). Yurda döndüğünde Erkan-1 Harbiye Binbaşıs1 rütbesiyle Mekteb-i Harbiye'de Riyaziye hocalığına atanmıştır (Mehmed Esad, 1310: 42). Matematiğe ilişkin eserleri mevcuttur (Bursalı Mehmet Tâhir, III, 2000: 279). 1835'teki İngiltere kafilesinde, Cambridge'e giden Emin Paşa'da mevcuttu. Mezuniyetini müteakip İstanbul'a döndüğünde Mirliva rütbesini alarak Harbiye Mektebi nazırı tayin edildi (1841). Mekteb-i Harbiye'de modern eğitimin yerleşmesinde öncü rolü üstlenmiştir. Emin Paşa matematik ve askeri meselelerde ciddi bir bilgiye sahipti. Ancak hayatının önemli bir bölümü idari görevlerle geçtiğinden pek fazla eser yazma firsatı bulamamıştır (Aydüz, 2008: 401). Diğer bir önemli şahsiyet, Mülazım-1 Sâni (teğmen) olarak tahsile giden ilk Türk ressamı, Ferik Ressam İbrahim Paşa'dır (1815-1891). Yurda döndüğünde hendese ve döküm işlerinde mahir olması sebebiyle Alay Eminliği rütbesiyle Tophane-i Amire'de istihdam olmuştur (BOA, HAT, 59197-D, 59197-E). İngiltere'de diğer Mühendishane mezunları gibi resim dersi alan İbrahim Paşa, bu husustaki yeteneğiyle ön plana çıkmış yaşadığı sürece aralarında Sultan Abdülmecid'in tablosunun da yer aldığı pek çok eser vermiştir (İslimyeli, 1965: 31; Gençoğlu, 2008a: 100). 
İngiltere'ye bu dönemde bahriyelilerin gönderilmeye başlanması önemlidir. Bunlardan Aziz Efendi yakalandığı verem hastalığı yüzünden 1838'de geri dönmek zorunda kalırken (BOA, HAT, 46439-B) Salih Efendi tahsilini tamamladıktan sonra (1255 1839/40) Tersane-i Amire vapurlarında istihdam edilerek kendisine kaymakamlık (Yarbay) rütbesi verilmiştir (BOA, HAT, 59164). Bu ülkeden gönderilen Bahriyeliler vasitasıyla vapur, gemi inşa teknikleri ve kaptanlık gibi denizciliğe ait bilgi ve becerinin taşınmasına gayret edilmiştir.

Denizcilik öğrenimi hususunda İngiltere'ye tanınan önceliğin sebebi, bu ülkenin denizler üzerindeki hâkimiyetiydi. 18. yüzyıl boyunca İngiliz Kraliyet Donanması genel olarak dünyanın en büyük donanması konumundaydı. 19. Yüzyıla baktığımızda da bu konuda değişen bir şey yoktur. Diğer güçlere nazaran asker sayısı düşük olmasına rağmen, İngiltere'nin büyük güç olmasında yatan en önemli faktörlerin başında karşı konulamaz bir deniz gücüne sahip olması gelmekteydi (Kennedy, 1993: 181). Nitekim 1815 'ten sonra sayısal açıdan düzenli olarak yapılan indirimlere rağmen Kraliyet Donanması, kimi zamanlarda fiili savaş gücü bakımından neredeyse kendinden sonraki üç ya da dört donanma kadar kuvvetliydi (Kennedy 1993: 182). Osmanlı devlet adamları, İngilizlerin üstün deniz gücünün farkındaydılar. Nitekim Mustafa Reşid Paşa (o sırada bey) Londra sefiriyken İstanbul'a gönderdiği 28 Şevval 1252 / 05 Şubat 1837 tarihli tahriratta, İngilizlerin denizcilik biliminde diğer Avrupa devletlerinden üstün olduklarını ve bu fenni tahsil edeceklerin İngiltere'ye gönderilmesinin gerekli olduğunu belirtiyordu (BOA, HAT, 37507-B). Zaten Osmanlı Bahriyesinin İngiliz usulünde teşkil edilmesi, bu husustaki eğitim hareketini de teşvik etmiştir (Gençoğlu, 2015).

II. Mahmud devrinde Fransa'daki öğrencilerin sayısı (24), çok az farkla da olsa Avusturya ve İngiltere'den sonra gelmektedir. Fakat Tanzimat döneminde diğer ülkelerle kıyas kabul edilmeyecek derecede çok Osmanlı öğrencisine ev sahipliği yapmıştır (Gençoğlu, 2008a: 62). Bunda Fransızcanın bütün Avrupa'da umumi lisan ve diplomasi dili olmasının yanı sıra eğitimin daha ucuz olmasının tesiri vardı (BOA, HAT, 37507-B). Ayrıca Osmanlı'da Batılaşmanın büyük ölçüde Fransız modeli üzerinden geliştiğini de unutmamak gerekir.

Öncü grubun akabinde bu ülkeye gönderilenler içerisinde Osmanlı ricalinin önde gelen isimleri vardır. Bunlardan Ecole de Metz mezunu olan Kıbrıslı Mehmed 
Emin Paşa (1813-1871) birçok askeri ve idari görevde bulunmuş Sultan Abdülmecid ve Sultan Abdülaziz zamanlarında üç defa sadrazamlığa getirilmiştir (Gövsa, 1933-35: 216; Şişman, 2004: 136). Abdülmecid devri müşirlerinden olup Harbiye Mektebi Nâzırlığında bulunmuş olan Rıfat Paşa (1810-1859) ise Paris'teki Saint Cry Harbiye Mektebi'ni pekiyi derecede bitirme başarısını göstermiştir (Gövsa, 1933-35: 326; BOA, HAT 37507-B). Paris’te askeri tahsil görenler arasında Mehmed Nâmık Paşa (1804-1892) da vard1. Kuruluşuna öncülük ettiği Mekteb-i Harbiye'nin gelişmesinde önemli katkıları olan Mehmet Namık Paşa, Ticaret Nazırlığı, üç defa Seraskerlik ve iki kez Bahriye Nazırlığı görevlerine atanmıştır (Kılıç, 2008: 348). Bir diğer önemli şahsiyet, asker ressamlar kuşağının ilk temsilcileri arasında yer alan Ferik Tevfik Paşa'dır (1819-1866). Tevfik, Enderun-1 Hümayun'dan 1835'te Fransa'ya giderek topçuluk tahsili görmüştür (Şişman 2004: 156). Paşanın yapıtları günümüze ulaşmadığından sanat üslubuna ilişkin kesin bir yorum yapılamamaktadır (İslimyeli, 1965: 32). Bu ülkeye gidenler içerisinde son olarak zikredeceğimiz kişi, askeri görevlerinin yanında Trablusgarb, Hersek ve Bursa valiliklerinde bulunmuş Ali Rıza Paşa'dır. Ali Rıza, Paris'te Askeri İdadi Okulunda 9 yıl topçuluk ve istihkâm eğitimi görmüş (Şişman, 2004: 101) mezuniyetini müteakip Tophane'de istihdam olmuştur (Mehmed Süreyya, III, 1311: 574-575).

Prusya'da (Almanya) tahsil yapanların sayısı II. Mahmud devrinde üç kişiyle sınırlı kalmıştır. Mekteb-i Harbiyeli bu üç talebe, 1839'un Mart ayında Berlin'e gitmişler ve bir Alman nazırın denetiminde iki yıllık bir hazırlık devresinden sonra astsubay okuluna kabul edilmişlerdir. Bu öğrenciler paşalığa kadar yükselmiş olan Ahmed, Râmiz ve Mehmed efendilerdir. Bu ülkenin Almanya İmparatorluğu'na terfi etmesinden sonra bilhassa II. Abdülhamid devrinde iki ülke arasındaki siyasi yakınlaşmayla gelişen askeri işbirliği neticesinde Alman orduları ve askeri okullarında yetişmek üzere bu ülkeye pey der pey birçok subay gönderilmiştir (Gençoğlu, 2014: $38)$.

\section{Yurtdışı Eğitimde Gayrimüslimlerin Payı}

Sultan II. Mahmud döneminde toplam sayının \% 20'sine karşılık gelen 18 gayrimüslim öğrenciye burs verildiği tespit edilmiştir. $\mathrm{Bu}$ da gayrimüslimlerin genel nüfustaki paylarına nazaran oldukça makul bir orandır. Aslında yurtdışı eğitimde gayrimüslimler, devletten önce harekete geçmişlerdi. 1830'dan önce bazı zengin 
gayrimüslim ailelerin çocuklarını Avrupa'ya okumaya gönderdikleri bilinmektedir (Gençoğlu, 2008a: 51). Devlet bursundan faydalanan gayrimüslimlerin çoğunluğunu Ermeniler oluşturmaktaydı. Ardından Ortodoks milletine mensup Bulgarlar gelmekteydi. $\mathrm{Bu}$ dönemde Avrupa’ya Rumlardan hiç kimse gönderilmemiştir. Kuşkusuz bunda başta Rum Patriği olmak üzere Osmanlı bürokrasisindeki Rumların gizliden gizliye Yunan Ayaklanmasını desteklemelerinin payı büyüktür. Keza ihaneti tespit edilen dönemin patriği V. Gregorius ve bazı metropolitlerin asılarak idam edilmesinin akabinde devlet nezdinde Rumlara duyulan güven tamamen sarsılmış ve devlet memuriyetlerinden çıkarılarak yerlerine Ermeniler alınmaya başlamıştır (Eryılmaz, 1990: 50-51). Ancak ilerleyen süreçte bu tavır değişmiş, Rumlar da yurtdış1 eğitimden faydalanmışlardır.

$\mathrm{Bu}$ dönemde fen tahsili için Paris’te bulunan Kaspar Sinapyan, Archigene Sarandi, Akef ve Aleksandri isimli dört Ermeni reayaya Osmanlı hükümetince verilen burs, Fransız gazetelerinde övgüyle bahsedilmiştir (BOA, İ. HR, 39). Bu dört Ermeni'den Kaspar Sinapyan Bey (1814-1872) II. Mahmud'un özel hekimi olan Ankaralı Kevork Ağa'nın oğluydu. Kaspar Sinapyan 1830'da Cerrahi Mektebi'ne girdi. 1835 'te Serope Viçenyan (Serviçen) ile Paris'e gitti. Oradan İtalya'ya Pisa Üniversitesi Tıp Fakültesi'ne geçip 1841 'de mezun oldu. 1845'te Tıbbiye Mektebi'ne muallim tayin olunan Kaspar, Valide Sultanın doktorluğunu da yapmıştır (Çark,1953: 94). Kaspar gibi tıp eğitimi alan diğer Ermeni Archigene Sarandi de yurda döndüğünde Mekteb-i Tıbbiye hocalığına atanmıştır (Kazancıgil, 1999: 261). Bu iki Ermeni, aynı zamanda Osmanlı'da tıp alanında devlet bursundan ilk faydalanan öğrenciler olmuşlardır (Gençoğlu, 2008b: 91).

Avrupa'da tahsil gören Ermeniler arasında Baruthanenin sorumluluğunu üstlenen Dadyan ailesi mensupları da vardı. Ohannes Dadyan (1798-1869), Azatlı Baruthanesi Barutçubaşıllğı görevini sürdürürken 1835'te II. Mahmud'un emriyle barut yapımı üzerine ihtisas edinmek üzere oğlu Arakel Sisak Dadyan ile İngiltere’ye gönderilmiştir. Baba-oğul, 1836'da İngiltere Kraliyet Baruthanesi’nden barut yapmayı öğrendiklerini tasdik eden bir şahâdetnâme almaya muvaffak olmuşlardır (BOA, HAT, 28921, 28921-A; Dabağyan, 2003: 717). Osmanlı Devleti’nin son baş-mimarı Sarkis Balyan'ın da kayınpederi olan Arakel Sisak, muhtelif devlet memuriyetlerinde bulunmuş ve Dadyanların son barutçubaşısı olarak tarihe geçmiştir. Ticaret Nezareti 
Sanayi Bölümü Müdürlüğü'ndeyken vefat etmiştir (Dabağyan 2003: 717-719). Dadyan sülalesinin devlet bursuyla Batı'ya giden bir diğer ferdi, Barutçubaşı Bogos Dadyan'ın en büyük oğlu Arakel Dadyan'dır (1821-1911). Arakel 1838'de barut yapımındaki gelişmeleri öğrenmek amacıyla arkadaşları Manuk ve Mardiros ile Londra'ya gönderilmiştir (BOA, HAT, 28874, 46403, 46435-E). Masrafları Baruthaneler Hazinesi'nden karşılanan bu üç arkadaş, Temmuz 1838'de Londra'ya ulaşmışlardır. Orada tahsilleriyle ilgili ihtiyaçları, Osmanlı Sefareti tarafından karşılanmıştır (BOA, HAT, 46397, 46439-C). 1840'da Arakel, diğer arkadaşlarıyla birlikte İstanbul'a dönmüştür (BOA, HAT, 48288, 48288-A; Dabağyan, 2003: 719721).

Ermenilerden başka bu süreçte yurtdışı eğitimden Ortodoks Bulgarların da faydalandığg görülmektedir. 1835'lerde altı Bulgar çocuğu, Bulgaristan'ın demir madenleri ve mamulleriyle ünlü Samakov kasabasından Londra'ya demircilik öğrenmek için gönderilmişlerdir. Bunlardan ikisi, hastalandıkları için birisi ise başarısızlığı sebebiyle iade olunmuşlardır. Geriye kalan üç kişi, Nisan 1840’ta öğrenimlerini tamamlayarak geri dönmüşlerdir (BOA, İ. HR, 148). Hatta bu çocuklardan Yenaki'nin gösterdiği gayret ve başarı taltife şayan bulunmuştur (BOA, HAT, 37529-F).

Gayrimüslim öğrenciler içerisinde, Osmanlı Devleti'ne büyük hizmetleri dokunan ünlü gazeteci Blak Bey’in (Alexander Blacque, 1792-1836) büyük oğlu Edouard Blacque da (1824-1895) vardı. Aslen Fransız olan Blak Bey'in ölümüyle geride kalan iki oğlundan büyüğü Edouard devlet tarafindan okutulmuş, Fransa'da akrabalarının himayesinde bulunan küçük oğlu Edmond için de bazı girişimlerde bulunulmuştur. Edouard'ın Fransa'da 1252 senesi Zilkaadesinde (Şubat/Mart 1837) girdiği okulun tüm masrafları Osmanlı Devleti tarafından karşılanmıştır (BOA, C.MF, 2534; 2736). 10-11 yaşlarında olan Edmond, masraflarının yarısının akrabası kalan yarısının Fransa Hükümetince karşılandığı bir okula giderken, kendi ülkesinden ziyade Osmanlı Devleti'ne bağlılığını beyan eden sözcükler kullandığı için söz konusu okulla ilişiği kesilmiştir. Bunun üzerine Osmanlı Hükümeti devreye girmiş, Fransa' da devlet bursuyla okutulan ağabeyi Edouard'ın maaşına zam yapılmak suretiyle Edmond'a yardım edilmesi kararlaştırılmıştır (BOA, HAT, 37471-A). 
Edouard, yurtdışı tahsilden sonra İstanbul'da Liman Odası'nda çalışmaya başlamış (1842), devletin desteğiyle 1845 'te Courrier de Constantinople gazetesini çıkarmıştır. 1853'te Osmanlı hariciyesinde görev almış, 1867'de Osmanlı Devleti'nin ilk ABD elçisi olmuştur. Matbuat müdürlüğü, Şûra-yı Devlet azalığı, Bükreş elçiliği gibi görevlerde bulunan Edouard, ilki 1877'de ikincisi 1893 'te olmak üzere iki kere Altıncı Daire-i Belediye reisi olmuştur (Koloğlu, 1994: 261).

\section{Sonuç}

Sultan II. Mahmud devrinde Batıya gönderilenlerin büyük çoğunluğu askeri amaçlı tahsil görmüştür. Bunda reformların ağırlık noktasının askeri olmasının yanı sıra mühendislik, tıp gibi yükseköğretim alanlarının da askeri amaçlara hizmet etmesinin rolü büyüktü. Tanzimat'la modernleşmenin hemen her alanda yaygınlaşması, zamanla sivil okulların kurulması ve gelişmesiyle yurtdışı eğitim alanları çeşitlilik kazanmaya başlamıştır. Fakat hiçbir zaman sivil öğrencilerin sayısı askeri öğrencileri geçememiştir.

Zaten bu dönemde askeri okullar, yenileşmeyi savunan ve yürüten kadroların yetiştirilmesi için pek de alternatifi olmayan çağdaş eğitim kurumlarıydı. Osmanlı/Türk modernleşmesinin mottosu olan bu kurumların öğretim ve idareci kadrolarında, yurtdışı eğitimle birlikte yabancıların yerini yurtdışı tahsilli yerli unsurların yavaş da olsa almaya başladıkları görülmektedir. Ayrıca istihdam edildikleri birliklerde Batılı usulde talimlerin öğretilmesinde ve atandıkları Tophane, Tüfenkhane, Baruthane, Dikimhane, Tersane gibi ordunun mühimmat ve donanımından mesul kurumların çağdaşlaşmasında önemli katkıları olmuştur.

Gayrimüslimlerin yurtdışı eğitimden faydalanma oranlarından da anlaşılacağı üzere başlangıçtan itibaren Osmanlı Devleti'nin bu hususta Müslüman olsun veya olmasın herhangi bir ayrımcılığa başvurmamıştır. Hatta kendi bütçesiyle tahsile gidenlerden zor duruma düşüp, yardım talep edenlere burs bağlanmış ve memlekete döndüklerinde devlet müesseselerinde istihdam edilmişlerdir.

Yurtdışı eğitimle modernleşmede model olarak alınan Batı'dan bilgi ve teknoloji transferinin direkt olarak yapılabilmesinin kapısı açılmıştı. Fakat genel olarak Rusya ile savaşlar, ayanla mücadele, Yunanistan Ayaklanması, Mısır sorunu, iktisadi yapıdaki bozukluklar ve reformlar için yapılan harcamalar gibi ciddi sorunlar Osmanlı Devleti'ni büyük bir siyasi ve mali bunalıma sokmuştu. Bu da gönderilenlerin 
Cilt: 3, S: 2, Mayıs 2020

ESOGÜ Tarih Dergisi

sayısının istenilen düzeyde gerçekleşmesinin önüne geçmiş; hedeflenen dönüşümün hızını oldukça yavaşlatmıştır. Dahası öğrencilerin tahsil sürelerinin uzun sürmesi, birçoğunun mezuniyetinin sultan tarafından dahi görülememesiyle sonuçlanmıştır. Tüm olumsuzluklara rağmen yurtdışı eğitimi özveriyle sürdürme çabası, sonraki dönemler için de teşvik edici bir işleve sahip olmuştur.

\section{Kaynakça}

A) BAŞBAKANLIK OSMANLI ARŞIVI (BOA) KAYNAKLARI

1) Hattı Hümayun Kataloğu (HAT) 26117, 26117-B, 33714-F, 33726-A, 33474, 58137, 48162-Z/2, 59189, 18615-D, 59189, 58137, 33733-F, 32281-E, 40833-B; 46746-B, 46752-D, 59197-D, 59197-E, 46439-B, 59164, 37507-B, 28921, 28921-A, 28874, 46403, 46435-E, 46397, 46439-C, 48288, 48288-A, 37529-F, 37471-A

2) İradeler 1255-1310 Katalogları, Hariciye (İ.HR): $39,148,149,453$

3) Cevdet Tasnifi (C.)

a) Cevdet Askeri (C.AS): 29175,32428, 37932, 54029

b) Cevdet Hariciye (C.HR): 6708

c) Cevdet Maarif (C.MF): 2521, 2534; 2736

B) KAYNAKLAR, ARAŞTIRMALAR ve BAŞVURU ESERLERİ

Ahmed Lütfi Efendi, Vak'anüvis Ahmed Lûtfí Efendi Tarihi, I, Tarih Vakfi-YKY, İstanbul 1999.

Akınc1, Gündüz, Türk-Fransız Kültür Illişkileri, Atatürk Üniversitesi Yayınları, Ankara 1973.

Akyıldız, Ali, Osmanlı Bürokrasisi ve Modernleşme, 4. baskı, İletişim Yayınları, İstanbul 2012.

Akyüz, Yahya, Türk Eğitim Tarihi, 25. baskı, Pegem Akademi, Ankara 2013.

Aydüz, Salim, "Derviş Paşa (Kimyager)", Yaşamları ve Yapıtlarıyla Osmanlılar Ansiklopedisi, I, 2. bask1, YKY, İstanbul 2008, 375-376.

Aydüz, Salim, "Emin Paşa", Yaşamları ve Yapıtlarıyla Osmanlılar Ansiklopedisi, I, 2. baskı, YKY, İstanbul 2008, 401.

Bursalı Mehmed Tahir, Osmanlı Müellifleri, I-III, (tıpkı basım), Bizim Büro Basımevi, Ankara 2000.

Çark, Y.,Türk Devleti Hizmetinde Ermeniler 1453-1953, Yeni Matbaa, İstanbul 1953.

Çelik, Yüksel, Şeyh'ül-vüzerâ Koca Hüsrev Paşa, II. Mahmud Devrinin Perde Arkası, Türk Tarih Kurumu, Ankara 2013.

Dabağyan, Levon Panos, Türkiye Ermenileri Tarihi, IQ Kültür Sanat Yayıncılık, İstanbul 2003.

Davison, Roderic H, Osmanlı İmparatorluğu'nda Reform, çev., Osman Akınhay, I, Papirüs, İstanbul 1997.

Eldem, Edhem, "Fransa'ya Eğitime Gönderilen Sadrazam İbrahim Edhem”, Popüler Tarih, 74, (Ekim 2006): 50-53.

Ergin, Osman Nuri, Türkiye Maarif Tarihi, II, Osmanbey Matbaası, İstanbul 1939.

Eryılmaz, Bilal, Osmanlı Devletinde Gayrimüslim Tebaanın Yönetimi, Risale Yayınları, İstanbul 1990.

Findley, Carter V., Osmanlı Imparatorluğu'nda Bürokratik Reform Babıâli, 1789-1922, çev., Ercan Ertürk, Tarih Vakfi Yurt Yayınları, İstanbul 2014.

Gencer, Ali ihsan, Bahriye'de Yapılan Islâhât Hareketleri ve Bahriye Nezâreti'nin Kuruluşu (17891867), 2. bask1, Türk Tarih Kurumu, Ankara 2001.

Gençoğlu, Mustafa, Osmanlı Devleti'nce Batı'ya Eğitim Amacıyla Gönderilenler (1830-1908) - Bir Grup Biyografisi Araştırmast-, Hacettepe Üniversitesi Sosyal Bilimler Enstitüsü, Doktora Tezi, Ankara 2008a.

Gençoğlu, Mustafa, "Başlangıçtan II. Meşrutiyet'e Osmanlı Devleti Tarafından Tıp Eğitimi için Avrupa'ya Gönderilenlerin Modern Türk Tibbına Katkıları". Kök Araştırmalar, 10 (1), 2008b, 89-115.

Gençoğlu, Mustafa, "Sultan II. Abdülhamid'in Yurtdışı Eğitim Politikası", Kırıkkale Üniversitesi Sosyal Bilimler Dergisi, 4 (2), 2014, 33-73.

Gençoğlu, Mustafa, "Batı Bilgi ve Teknolojisinin Osmanlı Bahriyesine Aktarımı", Tarih Araşstırmaları Dergisi, 34 (58), 2015, 619-644.

Gövsa, İbrahim Alaaddin. Meşhur Adamlar, I-IV, İstanbul 1933-35. 
İnal, İbnülemin Mahmut Kemal, Son Sadrazamlar, I-XIV. cüzler, Maarif Matbaası, İstanbul 1940.

İslimyeli, Nüzhet, Asker Ressamlar ve Ekoller, Asker Ressamlar Sanat Derneği Yayınları, Ankara 1965. Karal, Enver Ziya, Osmanlı Tarihi, V, Türk Tarih Kurumu, Ankara 1988.

Karpat, Kemal H., Osmanlı'da Değişim, Modernleşme ve Uluslaşma, çev., Dilek Özdemir, İmge Kitabevi Yayınları, Ankara 2006.

Kazancigil, Aykut, "İstanbul Üniversitesi Tip Fakültesinin (İstanbul- Cerrahpaşa) Tarihçesi Türkiye'de Çağdaş Tıp Eğitiminin Başlangıcı”, Tıp Tarihi Araştırmaları, 9, 1999, 254-309

Kennedy, Paul, Büyük Güçlerin Yükseliş ve Çöküşleri, çev. Birtane Karanakçı, 4. baskı, Türkiye İş Bankası Kültür Yayınları, Ankara 1993.

Kılıç, Abdullah, "Namık Paşa", Yaşamları ve Yapıtlarıyla Osmanlılar Ansiklopedisi, II, 2. baskı, YKY, İstanbul 2008, 348.

Koloğlu, Orhan, "Blacque, Edouard", Dünden Bugüne İstanbul Ansiklopedisi, II, Türkiye Ekonomik ve Toplumsal Tarih Vakfi, 1994, 261.

Lewis, Bernard, Modern Türkiye'nin Doğuşu, Çev, Metin Kıratlı, TTK Basımevi, Ankara 2000.

Mahmud Cevad İbnü'ş şeyh Nâfi, Maârif-i Umûmiye Nezâreti Tarihçe-i Teşkilât ve İcrââtı - XIX. Asır Osmanlı Maârif Tarihi, haz., Taceddin Kayaoğlu, Yeni Türkiye Yayınları, Ankara 2001.

Mardin, Șerif, Türk Modernleşmesi, Makaleler 4, Der., Mümtaz'er Türköne ve Tuncay Önder, 3. bask1, İletişim Yayınları, İstanbul 1994.

Mehmed Esad, Mir'at-l Mekteb-i Harbiye, Artin Asadoryan Matbaası, İstanbul 1310.

Mehmed Esad, Mir'at-ı Mühendishâne-i Berrî-i Hümâyun, Karabet Matbaası, İstanbul 1312.

Mehmed Süreyya, Sicill-i Osmani Yâhud Tezkere-i Meşâhir-i Osmaniye, II-IV, Matbaa-i Âmire, İstanbul 1311.

Özcan, Abdülkadir, “Abdülkerim Nâdir Paşa (1807-1883)”, Diyanet İslam Ansiklopedisi, I, 1988, 253254.

Riza Tahsin, Mirat-1 Mekteb-i Tıbbiye, I, Kader Matbaası, İstanbul 1328.

Soysal, İsmail, Fransız İhtilali ve Türk Fransız Diplomasi Münasebetleri (1789-1802), Türk Tarih Kurumu, Ankara 1987.

Şişman, Adnan, Tanzimat Döneminde Fransa'ya Gönderilen Osmanlı Öğrencileri (1839-1876), Türk Tarih Kurumu, Ankara 2004.

Shaw, Stanford J. - Shaw, Ezel Kural, Osmanl Imparatorluğu ve Modern Türkiye, II, çev. Mehmet Harmanc1, 3. bask1, E Yayınları, İstanbul 2010.

Tuğlacı, Pars, The Role of the Dadyan Family in Otoman Social, Economic and Political Life, Pars Yayınları, İstanbul 1993.

Uluçay, Çağatay-Kartekin, Enver, Yüksek Mühendis Okulu, İ.T.Ü Makine Fakültesi, İstanbul 1958.

Uludağ, Osman Şevki, Beş Buçuk Asırlk Türk Tababeti Tarihi, haz. İlter Uzel, Kültür Bakanlı̆̆ Yayınlar1, Ankara 1991.

Unat, Faik Reşit, Türkiye Eğitim Sisteminin Gelişmesine Tarihi Bir Bakış, MEB Yayınları, Ankara 1964.

Uzunçarşıl1, İsmail Hakkı, "İbrahim Edhem Paşa Ailesi ve Halil Edhem Eldem (1681-1938)”, Halil Edhem Hattra Kitabl, II, Ankara 1948: 67-70

Yazıcı, Nesimi, "Takvîm-i Vekâyi”, Diyanet İslam Ansiklopedisi, 39, İstanbul 2010: 490-492.

Yeşil, Fatih, Aydınlanma Çağında Bir Osmanlı Kâtibi Ebubekir Râtib Efendi (1750-1799), Tarih Vakfı Yurt Yayınları, İstanbul, 2011. 